\title{
PENGARUH BIAS PEMAHAMAN SUBSTANSI DASAR TEORI MUSIK TERHADAP KEMAMPUAN PRAKTEK INSTRUMEN GESEK DI SENDRATASIK UNP
}

\section{THE EFFECTS OF BIAS UNDERSTANDING OF BASIC SUBSTANTIAL OF MUSIC THEORY TOWARDS THE ABILITY OF STRING INSTRUMENTS PRACTICE IN SENDRATASIK UNIVERSITAS NEGERI PADANG}

\author{
Yensharti ${ }^{1}$; Yos Sudarman; \\ 1,2Jurusan Sendratasik, Fakultas Bahasa dan Seni Universitas Negeri Padang \\ $\left.{ }^{*}\right) \bowtie$ (e-mail) yensharti@fbs.unp.ac.id ${ }^{1}$
}

\begin{abstract}
Abstrak
Artikel ini adalah hasil penelitian yang bertujuan untuk menjelaskan dan mendeskripsikan adanya pengaruh bias (penyimpangan) pemahaman substansi dasar teori musik pada mahasiswa program keahlian musik di Prodi Pendidikan Sendratasik FBS UNP terhadap kemampuan praktikum memainkan alat musik instrumen gesek. Sebab dapat diduga bahwa terdapat hubungan kausal antara pemahaman yang benar tentang teori musik terhadap meningkatnya kemampuan melaksanakan praktikum instrumen gesek dalam matakuliah praktek instrumen.

Kemampuan membaca notasi berhubungan langsung dengan tingkat pemahaman tentang teori musik. Jika kemampuan membaca notasi mahasiswa rendah, kemampuan gesek juga instrumen cenderung rendah, yang dapat diduga karena salah memahami besaran nilai dan makna-makna simbolis notasi yang dipelajari dalam kuliah teori musik atau pengetahuan dasar musik yang pernah didapatkan di bangku sekolah menengah, Sehingga masalah ini juga sesuatu yang bersifat simultan (berkelanjutan) terhadap rendahnya mutu permainan instrumen gesek tersebut.
\end{abstract}

Kata kunci: bias pemahaman; teori musik; praktek instrumen gesek

\section{Abstract}

This study aims to explain and describe the effect of bias (deviation) on the basic substance understanding of music theory in music skills program students at FBS UNP Sendratasik Education Study Program on practical ability to play stringed instruments. Because it can be assumed that there is a causal relationship between a correct understanding of music theory towards the increased ability to carry out stringent instrument practicum in instrument practice subjects.

This research can be observed during the lecture on the practice of string instruments, researchers feel the need to examine this issue more deeply, including whether the basic substance deviation of music theory understood by students comes from lectures in Music Theory and the like in FBS UNP Sendratasik Education Study Program, or even understanding bias which has taken root since students received knowledge of music theory in art and culture lessons from teachers while in high school.

Keywords: bias understanding; music theory; string instruments practice 


\section{Pendahuluan}

Universitas Negeri Padang sebagai LPTK (Lembaga Pendidikan Tenaga Kependidikan) memiliki jurusan dan program studi yang menyalurkan minat yang dapat menelusurkan kemampuan mahasiswa untuk siap menjadi tenaga pendidik, salah satunya pada bidang disiplin ilmu seni budaya, untuk eksis menjadi guru/calon guru di lembaga pendidikan setingkat sekolah menengah. Jurusan Sendratasik (Seni Drama Tari dan Musik) FBS Universitas Negeri Padang, bersama Prodi Pendidikan Seni Drama Tari dan Musik, tidak ketinggalan dengan misi itu, di mana sudah sejak tahun 1995 menapaki dua program keahlian setingkat strata satu (S-1) yaitu keahlian musik dan keahlian tari.

Sebagai lembaga akademik yang melaksanakan pendidikan dalam aktifitas pembelajarannya, maka prodi Pendidikan Sendratasik FBS UNP menerapkan Sistem Kredit Semester (SKS) kepada mahasiswa untuk bisa melaksanakan dan menyelesaikan studi dengan mengikuti matakuliah-matakuliah yang telah dipersyaratkan dalam kurikulum yang berlaku. Saat ini Prodi Pendidikan Sendratasik FBS UNP sedang memberlakukan penerapan Kurikulum Kualifikasi Nasional Indonesia (KKNI) di mana terdapat matakuliah-matakuliah yang saling berhubungan dan kadang dipersyaratkan. Kuliah Teori Musik I dan II serta mata kuliah Praktek Instrumen (gesek) merupakan beberapa mata kuliah keilmuan dasar yang memiliki korelasi yang erat, terutama hubungan antara pengetahuan dan pemahaman substransi dasar teori musik yang akan berpengaruh terhadap kemampuan mahasiswa membaca notasi dan kuliah praktek instrumen gesek pada khususnya.

Mempelajari teori musik pada program keahlian musik setingkat perguruan tinggi berarti mempelajari substansi keilmuan dasar yang menjelaskan unsur-unsur musik. Cabang ilmu ini mencakup pengembangan dan penerapan metode untuk menganalisis maupun menggubah musik, dan keterkaitannya dengan notasi musik dan memainkan alat musik sangatlah dekat dan erat. Artinya, mahasiswa tidak akan mampu memainkan alat musik, atau membaca notasi musik, atau memainkan alat musik dengan membaca notasi musik dengan baik, jika tidak memahami substansi dasar teori musik dengan baik. Itulah alasannya mengapa mata kuliah teori musik ini diberikan sejak semester awal kepada mahasiswa program keahlian musik, yang dimaksudkan untuk membangun pengertian dan pemahaman tentang substansi dasar teori musik, yang lebih teoritis dan lebih kritis sejak awal. Karena teori musik sudah diperkenalkan lebih awal itu pula, diharapkan pengetahuan tentang teori musik ini juga akan lebih fuungsional untuk menunjang pengetahuan dan praktikum dalam matakuliah selanjutnya, yang tentunya akan lebih kompleks dan lebih rumit.

Namun sebagai bagian dari staf pengajar bidang keahlian musik di Prodi Pendidikan Sendratasik FBS UNP, peneliti dan tim menemukan beberapa gejala awal yang bisa dikategorikan sebagai fakta permulaan, bahwa dengan tetap menggunakan perangkat perkuliahan yang sama dan metode perkuliahan yang sama pada mata kuliah praktek instrumen gesek, terlihat ada penurunan kemampuan dari mahasiswa peserta kuluiah saat memainkan inbstrumen gesek (seperti violin) dengan membaca lagu yang ada di partitur. Dengan kata lain, di beberapa rombongan belajar peserta kuliah dalam kuliah praktek instrumen gesek di tahun-tahun terakhir, nampaknya terjadi penurunan kecepatan membaca dan daya tangkap mahasiswa dalam memahami notasi musik (notasi balok) yang dibaca di partitur yang akan memandunya untuk memainkan instrumen gesek. Dugaan ini semakin kuat saat mahasiswa diminta untuk sekedar membaca notasi musik dari sebuah sampel lagu di partitur, yang hasilnya adalah ketidakpahaman mahasiswa membaca notasi di partitur 
tersebut. Ada beberapa mahasiswa memang yang mengerti atau paham dengan makna simbol dan nilai notasi yang ia baca, namun saat diterapkan dalam permainan musik, kecepatan membaca partitur dalam permainan menjadi lambat. Saat mahasiswa ditanya, "Apakah sudah pernah belajar tentnag simbol yang ada dalam notasi lagu yang dibaca?" Umumnya mereka menjawab sudah. Namun saat diminta untuk menerapkannya secara musical peformance (unjuk kerja musik) dalam praktek, mahasiswa relatif kurang mampu.

Dengan tidak mendiskreditkan pihak manapun dalam bentuk apapun, peneliti dan tim menduga kalau masalah ini terjadi bukan karena mahasiswa belum belajar teopri musik sama sekali, Juga bukan karena pemanfaatan teori musik dalam praktek instrumen gesek salah terapan. Penulis dan tim lebih tertarik untuk membuat asumsi awal bahwa nampaknya telah terjadi bias (penyimpangan) di beberapa konsep tentang teori musik yang diterima dan dipahami mahasiswa, yang menyebabkan sistem pengetahuan musik dan penerapannya menjadi tidak utuh dan tidak dalam pemahaman yang sistemik. Penyimpangan (bias) konsep ini malahan bukan gejala yang terjadi saat mahasiswa belajar di kampus semata, melain juga sudah terbentuk saat mereka pernah mendapatkan pengetahuan tentang musik dalam pelajaran seni budaya saat mereka masih belajar di sekolah menengah (SMP/SMA). Seperti disebutkan di atas, bahwa penelitian ini bukan untuk mengevaluasi kinerja pembelajaran musik pada pihak lain, maka penelitian ini akan difokuskan pada pendeskripsian data lisan, tulisan, dan unjuk kerja mahasiswa dari pelaksanaan mata kuliah praktek instrumen gesek yang menggunakan notasi sebagai landasan praktek instrumennya.

Sedangkan masalah dalam penelitian ini dirumuskan dengan: "Bagaimanakah pengaruh bias pemahaman substansi dasar teori musik terhadap kemampuan praktikum kuliah praktek instrumen gesek di Prodi Pendidikan Sendratasik FBS UNP?" Berikutnya tujuan penelitian ini adalah mendeskripsikan adanya pengaruh bias pemahaman substansi dasar teori musik terhadap kemampuan praktikum kuliah praktek instrumen gesek di Prodi Pendidikan Sendratasik FBS UNP.

Sebagai upaya menjawab permasalahan di atas, maka beberapa kajian kepustakaan yang digunakan dalam penelitian ini adalah teori-teori yang berhubungan dengan teori musik dan beberapa teori pendukung lainnya. Teori musik adalah salah satu pengetahuan dasar bidang musik, yang posisinya sangat penting dalam tataruang keilmuan musik yang sebagain besar pondasinya sudah dibukakan dan dibakukan sejak lama, sehingga pengetahuan tentang teori musik secara basis teori tidak lagi berkembang, namun yang berkembang itu adalah bentuk-bentuk penerapannya dalam jejaring ilmu musik yang tumbuh di atasnya. Itulah sebabnya, tinjauan kepustakaan bidang teori musik "yang bebar-benar dianggap baru" memang agak sulit ditemukan, kecuali yang ditampilkan kembali dalam hasil penelitian, jurnal, dan buku-buku musik, adalah dalam bentuk repetisi (mengulang), reaktualisasi (menghadirkan) atau revitalisasi (memperbaharui) kembali dari substansi dasar musik yang sudah dikembangkan sejak zaman musik moderen dari Abad Pertengahan termasuk sejak musik zaman Klasik hingga sekarang.

Pembahasan musik dari sudut pandang estetika bunyi, telah menempatkan musik sebagai media ungkap pikiran atau perasaan manusia melalui bunyi yang diformulasikan ritme dan nada sebagai unsur dasarnya. Unsur dasar musik itu akhirnya akan menjangkau aspek-aspek lain yang lebih luas dan dengan pengertian yang lebih dalam, yaitu elemenelemen musik. Elemen musik dimaksud terdiri dari elemen ritmis, melodis, harmonis, ekspresi, dan bentuk (Sylado, 1981). Tidak ketinggalan juga (Banoe, 2003, p. 13) menjelaskan bahwa musik adalah karya cipta berupa bunyi atau suara yang memiliki nada, irama, dan 
keselarasan. Sedangkan menurut Jamalus (1989: 11), musik yang dimainkan menjadi komposisi terpadu dan berkesinambungan dapat memberikan pengaruh terhadap emosi dan kognisi. Musik adalah karya cipta berupa bunyi atau suara, baik suara yang dihasilkan oleh ucapan manusia maupun suara dari alat tertentu.

Selanjutnya praktek instrumen adalah salah satu bentuk kegiatan bermusik, yang didasari dengan penggunaan media alat musik sebagai sumber bunyi utama dalam musiknya. Instrumen violin, viola, cello dan sebagainya, adalah salah satu bentuk instrumen yang termasuk ke dalam kelompok alat musik gesek berdawai (chordophon) sebagaimana yang telah diklasifikasikan oleh Curt Suach dan Hornbostel bahwa, "Chordophon - sound is primarily produced by the vibration of string or string that are stretched between fixed point. This group includes all instrument generally called string instrument in the west, as well as many (but not all) keyboard instrument, such as piano and harpsichords" Sedangkan definisi tentang praktek instrumen musik adalah memainkan musik dengan suatu peformance (yang dipertunjukkan), yang biasa disebut dengan permainan musik menggunakan alat musik. Digunakannya kata "permainan musik" dari praktek musik yang menggunakan alat ini, sudah dipaparkan oleh Safrina (1999: 2), apapun wujud musik dalam segala kerumitannya, yang jelas musik itu adalah stau hasil karya seni bunyi dalam bentuk lagu atau komposisi musik yang dapat dimainkan, di mana permainan tentang lagu atau komposisi musik yang dimainkan, di mana permainan tentang lagu dan komposisi itu dapat mengungkapkan pikiran dan perasaan penciptanya melalui unsur-unsur utama musik yaitu irama dan nada.

\section{Metode}

Metode yang digunakan dalam penelitian ini adalah penelitian kualitatif dengan pendekatan deskriptif analisis (Miles, Huberman, \& Saldana, 2013). Nazir (1988) menjelaskan bahwa metode deskriptif merupakan suatu metode dalam meneliti suatu status kelompok manusia, suatu objek, suatu set kondisi, suatu sistem pemikiran, ataupun suatu kelas peristiwa pada masa sekarang. Tujuan dari penelitian deskriptif ini adalah untuk membuat deskripsi, gambaran, dan lukisan secara sistematis, faktual, dan akurat mengenai fakta-fakta, sifat-sifat serta hubungan anta-fenomena yang diselidiki.

Dengan menggunakan metode penelitian deskriptif-kualitatif ini, maka tahapantahapan penelitian yang pertama adalah melakukan observasi ulang (kelanjutan dari observasi awal) yang telah dilakukan sebelum membuat proposal penelitian. Kemudian mengumpulkan data dengan menjaring suatu gejala, fakta, pendapat orang, yang berkemungkinan ada hubungannya dengan masalah penelitian yang akan diteliti. Setelah itu mendiskusikan secara teamkwork dengan anggota peneliti lainnya untuk melakukan penyaringan data dan fakta apa saja yang benar-benar mempunyai posisi yang kuat dan jelas berhubungan dengan masalah penelitian.

Untuk kebutuhan sumber data secara personal, maka penelitian ini menggunakan sumber berupa informasi penelitian yang terdiri dari seluruh mahasiswa program keahlian musik pada Prodi Pendidikan Sendratasik FBS UNP yang mengikuti matakuliah Praktek Instrumen pada semester Juli-Desember 2017. Dengan proses pengumpulan data secara wawancara, observasi, dan studi dokumentasi, maka seluruh proses ini akan dapat dilakukan saat pra informasn (mahasiswa) mengikuti matakuliah dan dilibatkan secara inten dan frekuen dengan kegiatan memainkan instrumen gesek menggunakan sistem pembacaan partitur notasi. Dari setiap keterbatasan dan ketidakpahaman mahasiswa dalam mentransformasikan pengetahuan musiknya ke dalam permainan gesek itui, disitulah dicata, 
diwawancarai, dan diobservasi, bagaimana bentuk bias substansi dasar teori musik yang telah menyebabkan mereka sulit melakukan unjuk permainan instrumen gesek menggunakan notasi.

\section{Hasil dan Pembahasan}

Hasil penelitian yang dipaparkan pada bagian ini mengacu pada lima tahapan penelitian yang telah dijelaskan dalam rancangan penelitian, yaitu tahapan persiapan penelitian, tahapan pengumpulan data, tahapan analisis data, tahapan pelaporan hasil penelitian, dan tahapan publikasi ilmiah.

Pada tahapan persiapan penelitian ini telah dilakukan sejak awal semester Januari-Juni 2017 atau pada awal semester genap tahun akademik 20016/2017 di Program Studi Pendidikan Sendratasik (khususnya pada program keahlian musik) pada Jurusan Sendratasik FBS UNP. Beberapa bentuk kegiatan persiapan penelitian sebagaimana yang dimaksud di atas, sebagian telah dijelaskan dalam proposal penelitian yang diajukan dan disetujui pada bulan Juni 2016. Persiapan penelitian ini telah dimulai pada bulan Januari dan Februari 2017, yaitu dengan membuat asumsi awal bahwa kemampuan memainkan instrumen gesek mahasiswa keahlian musik Prodi Pendidikan Sendratasik FBS UNP pada matakuliah praktek instrumen, sebagian faktornya berasal dari adanya pemahaman konsep yang bias dari substansi dasar teori musik yang pernah dipelajari mahasiswa, khsusnya yang berhubungan dengan membaca notasi.

Menyadari sepenuhnya persoalan yang dihadapi, tentunya akan berdampak langsung terhadap mutu pembelajaran musik di program studi Pendidikan Sendratasik dan mutu lulusannya, maka sebagai calon ketua peneliti waktu itu yang mempunyai ide dalam masalah ini, saya mengajak rekan sejawat dari keilmuan pembelajaran seni musik untuk dilibatkan menjadi anggota tim peneliti. Dengan melakukan beberapa kali diskusi awal dengan rekan sejawat itulah, akhirnya ditarik dugaan sementara bahwa sebagian dari faktor penyebab rendahnya kemampuan memainkan instrumen gesek mahasiswa program keahlian musik di Prodi Pendidikan Sendratasik adalah adanya faktor bias konsep dasar teori musik yang dipahami mahasiswa. Hal ini bisa dijelaskan karena saat masa melakukan diskusi awal dengan rekan sejawat ini, juga pernah dilakukan tes awal bagi mahasiswa yang mengambil mata kuliah praktek instrumen gesek pada saat itu, yaitu mahasiswa semester II angkatan 2016 sebanyak 16 orang, di mana hasil penelusuran terhadap kemampuan teoritis musik mereka yang akan menunjang dalam membaca notasi dalam kuliah praktek instrumen memang bervariasi.

Hasil penelitian pada tahapan ini telah menerangkan bahwa dari 16 mahasiswa yang mengikuti tes awal ini, ada 9 mahasiswa atau sekitar 56,25\% mahasiswa yang kurang memahami konsep teori musik yang berhubungan dengan besaran nilai not dan makna simbolis yang mesti dimengerti dan dipahami mahasiswa saat membaca notasi dalam melaksanakan praktek instrumen nantinya. Namun demikian, walaupun hasil survei awal penelitian ini mengarah kepada beberapa matakuliah pendukung teori musik seperti Teori Musik 1 dan 2 yang sudah dan sedang ditempuh mahasiswa, perlu peneliti tegaskan bahwa penelitian ini bukan dimaksudkan untuk mengevaluasi kinerja pembelajaran musik pada pihak lain yang melaksanakan kedua matakuliah tersebut. Sebab, menurut pertimbangan peneliti, bukan matakuliah teori musik itu saja yang akan mengkonstruksi pengetahuan dan pemahaman mahasiswa tentang substansi dasar musik yang ada dalam pemahaman mereka, melinkan banyak faktor eksternal lainnya yang juga telah mengkonstruksi pengetahuan dan 
pemahaman musik tersebut, sehingga mahasiswa mengalami bias pemahaman dalam konsep dasar musik yang ada dalam pikirannya.

Sementara sesuai dengan penjelasan jenis penelitian, instrumen, dan teknis pengumpulan/analisis data di atas, maka sejak bulan Maret sampai Mei 2017 atau selama tiga bulan, peneliti dan tim telah melakukan pengumpulan data penelitian. Secara terinci pengumpulan data penelitian ini bisa dibagi menurut kornologis tiga bulan dimaksud, yaitu sebagai berikut:

1. Data yang terkumpul dengan observasi, yang dilakukan selama bulan Maret 2017 dalam kegiatan PBM (Proses Belajar Mengajar) atau pada perkuliahan praktek instrumen gesek yang diikuti oleh mahasiswa semester II tahun masuk 2016 sebayak 16 orang, telah menerangkan bahwa:

a) Dalam memainkan instrumen gesek, seperti violin, ada mahasiswa yang bisa diamati telah melakukan latihan memainkan violin dengan tanpa memahami notasi musik dan memang terlebih dahulu perlu memahami teori musik.

b) Bagi mahasiswa yang tidak mengindahkan teori musik, umumnya mereka cenderung lebih menfokuskan latihan kepada teknis penjarian, yang ketika mereka disuruh membaca notasi untuk permainan geseknya, mereka lebih banyak melakukan imitasi (meniru) kegiatan memainkan violin seperti yang dilakukan oleh temannya yang bisa membaca notasi.

c) Sedangkan bagi mahasiswa yang mengerti dengan notasi, nampaknya mereka lebih mudah untuk meningkatkan kemampuan geseknya dari tahap yang satu ke tahapan yang lebih tinggi. Tapi patut dicatat, di antara mahasiswa itu ada juga yang mau bertanya jika mereka tidak mengerti dengan besaran nilai not dan simbol notasi yang ia baca untuk permainan geseknya. Namun ada juga mahasiswa yang tidak perlu bertanya, dan sepertiya dui antara mahasiswa kelompok ini ada yang memahami konsep dasar notasi yang bias (menyimpang), tapi mereka tidak menyadari hal itu.

2. Dengan wawancara, telah dilakukan selama bulan April 2017 dalam kegiatan PBM (Proses Belajar Mengajar) atau pada perkuliahan praktek instrumen gesek yang diikuti oleh mahasiswa semester II tahun masuk 2016 sebayak 16 orang. Observasi penelitian ini tepat dilakukan selama 4 (empat) kali wawancara pada 16 orang mahasiswa selama empat minggu kegiatan penelitian. Adapun hasil wawancara yang peneliti lakukan secara wawancara terstruktur bersama dengan tim peneliti adalah sebagai berikut:

a) Untuk beberapa pertanyaan wawancara yang berhubungan dengan sikap belajar praktek instrumen gesek ini, sebagian dari jawaban mahasiswa memang mengindikasikan adanya mahasiswa yang tidak peduli dengan kemampuan awal teori musik yang mendukung kemampuan membaca notasi dalam pemainan musik gesek, dan sebagain mahasiswa lainnya menganggap hal itu perlu.

b) Bagi mahasiswa yang tidak mempedulikan kemampuan teori musik ini, ada yang memjawab tidak penting pemahaman notasi, asalkan kemampuan teknis menggesek violin yang dilakukan tepat. Kata mere, "Untuk apa bersusah payah mempel;ajari teori musik, sementara teknik penjarian dan ketepatan menggesek nada violin tidaklah tepat." Sebagai staf pengajar yang membinan matakuliah ini tetap mengimbau mahasiswa untuk mel;uruskan kembali idealisme mereka tersebut, meskipun sebenarnya apa yang dibayangkan mahasiswa kelompok ini bahwa ada orang yang piawai bermain violin tidak perlu mengenal notasi musik sebelumnya juga tidak terbantahkan adanya. 
c) Sedangkan bagi mahasiswa yang memang taat aturan dan taat terhadap perkembangan kemampuan teknis yang juga didukung oleh kemampuan teoritis, maka mereka memang merasa perlu untuk mengenal teori musik lebih dalam dan lebih paham, sehingga pemahaman itu telah disadarinya akan membantu mereka untuk dapat membaca notasi musik dengan baik saat memainkan violin. Tapi dari kelompok mahasiswa yang dalam wawancara, menjelaskan perlu belajar notasi ini, juga ditemukan mahasiswa yang terlalu kritis namun tidak aplikatif. Mereka sebagian memang dapar menjelaskan besaran nilai not dan makna simbol notasi yang dibacanya, namun tidak tepat pula dalam mempraktekkan pada permainan instrumen geseknya.

3. Seterusnya dengan studi dokumentasi, telah dilakukan selama bulan Mei 2017 dalam kegiatan dokumenter terhadap hasil-hasil perkuliahan, misalnya dari arsip hasil belajar yang dikumpulkan dan dikelompokkan. Hasil dokumentasi ini akhirnya lebih banyak mengambil data ujian harian, ujian tengah semester, termasuk hasil ujian mid dan semester dari matakuliah Teori Musik yang pernah dijalani mahasiswa pada semester sebelumnya.

Berdasarkan cara menganalisis data di atas, maka dapat dijelaskan hasil analisis data penelitian sebagai berikut:

1. Memenuhi kriteria analisis kualitatif secara reduksi data, maka dari 16 orang mahasiswa yang mengikuti kuliah praktek instrumen yang diteli, setelah direduksi (dipilih, dan dipilah) dapat dikelompokkan sebagai berikut:

a) Kelompok pertama, terdapat mahasiswa yang memiliki kemampuan gesek yang baik secara teknis, tapi secara teoritis mereka merasa tidak perlu memahaminya lebih mendalam.

b) Kelompok kedua, terdapat mahasiswa yang memiliki kemampuan gesek yang kurang baik secara teknis, tapi secara teoritis mereka memiliki pemahaman yang baik terhadap membaca notasi yang didukung oleh kemampuan teori musiknya yang baik pula.

c) Kelompok Ketiga, terdapat mahasiswa yang memiliki kemampuan gesek yang baik secara teknis, dan secara teoritis mereka memiliki pemahaman yang baik terhadap membaca notasi yang didukung oleh kemampuan teori musiknya yang baik pula.

Sementara ini dulu hasil penelitian yang dapat dipaparkan sampai pada bulan ke-10 pelaksanaan penelitian ini, yang nantinya akan senantiasa diperbaharui dan disempurnakan sesuai dengan kronologis tahapan penelitian.

\section{Kesimpulan}

Dengan selesainya pelaksanaan penelitian beserta diraihnya hasil-hasil penelitian sesuai dengan target yang telah ditetapkan maka diharapkan hasil penelitian ini berkontribusi mendasar terhadap pengembangan ilmu pengetahuan khususnya secara timbal balik antara teori musik dan alikasinya dalam praktek isntrumen musik, khususnya di Jurusan Sendratasik FBS UNP. Lebih dari itu, penelitian ini juga menyarankan bahwa berbagai kesalahan atau bias (penyimpangan) pemahaman musik di kalangan mahasiswa, ada baiknya ditelusuri dan dicarikan jalan keluarnya, agar pengetahuan dan pemahaman musik yang didapatkan dari belajar secara teori dan praktek tersebut menjadi utuh dan tidak keliru, yang tentunya akan membantu sipebelajar untuk dapat mengembangkan diri bersama ilmu pengetahuan yang dipelajarinya. 


\section{References}

Banoe, P. (2003). Kamus Musik Kanisius. Yogyakarta.

Cursach \& Hornbvostel. (1914). Clasification of Musical Instrument. Toronto: Volume 46, as part og digital collection of the university of Toronto.

Jamalus (1989). Pengajaran Seni Musik. Jkarta. Proyek Pengembangan Lembaga Pendidikan Tenaga Kependidikan Departemen P\&K.

Lovelock, William. (1980). A Student's Dictionary of Music. London: Bell \& Yman Limited.

Miles, M. B., Huberman, A. M., \& Saldana, J. (2013). Qualitative data analysis. Sage.

Nazir, M. (1988). Metode Penelitian. Jakarta: Ghalia Indonesia.

Sylado, Remuy. (1981). Menuju Apresiasi Musik. Bandung: Angkasa.

Safrina, Rien. (1999). Pendidikan Seni Musik. Bandung: Maulana. 